\title{
The Architectural Engineering Technology Applied Research Assistant Program at the Bluefield State College Center for Applied Research and Technology
}

\author{
Donald G. Bury, and Bruce V. Mutter \\ dbury@bluefieldstate.edu \\ bmutter@bluefieldstate.edu
}

Bluefield State College Center for Applied Research and Technology

\begin{abstract}
The paper highlights the development of the Bluefield State College (BSC), Center for Applied Research and Technology (CART), Applied Research Assistant (ARA) program to provide teams of Architectural Engineering Technology (ARET) students with in-house internship experience. The primary goal of the a ARA Program is to provide valuable real project work experiences to students, while allowing professionals to obtain specific limited services at substantially reduced costs, while freeing their staff to perform more complex activities in the office. The ARA Program was designed to provide a wide range of services to local professionals and businesses in the region. Anticipated services that will be available include; architectural design and drafting, graphic services, existing conditions drawings for building renovations, "as-built" drawings for completed projects, and product research. These services are intended to provide assistance in short duration projects, under the direct supervision of architects, professional engineers and industrial managers.
\end{abstract}

As identified in the ARET Department's TAC-ABET Continuous Improvement Plan (CIP), program outcomes have been devised to describe what graduates of a degree program will be able to demonstrate and know when they graduate. The skills and abilities identified in the program outcomes are measures of the quality of the program and can have a significant impact on the validity of the degree. Professional experience through an internship program, whether conducted in an office or through a program such as this, can enhance a student's understanding of the career field and practice, ultimately creating a better quality student. The process of obtaining professional internships in a rural area is significantly more difficult than in larger urban areas. Economic conditions in the state and region have magnified this problem. The initial contacts with professional offices and industries in the region have identified several companies who are interested in contracting for the services provided in this program.

The research will analyze the levels of student capability to provide independent and supervised services. Cost analysis will include contractile agreements; hourly rates and contract amounts. Initial projects have experienced success by improving some aspects of a companies operation. Companies will also benefit from access to an excited student labor pool. 


\section{Introduction}

The project addresses an emerging opportunity in undergraduate education by providing real project work experiences in an in-house setting. The goals and objectives of this project will require cooperative, technology and academic innovation. The initial operation of the project has seen a record of success, and is providing worthwhile pursuits consistent with the ultimate aims of our industry. Thus far the projects undertaken by the ARA program have proven realistic in smaller scale execution. The project has the potential for improving student learning of important AEC principles through the creation of innovative and supportive real project learning environments that develop student-teacher- client interaction.

Since the inception of the ARET - AS and BS programs at BSC, a primary concern has been improving program quality and the educational experiences of our students. Over the past few years, the department has received increasing requests by professionals and individuals to involve students in architectural, engineering and industrial projects. Such requests are difficult to include inside one of the current ARET design courses due to difficulties with project timing, scheduling, and the ability to meet the courses ability to achieve published program outcomes. The ARET curriculum offers courses that have been designed to serve as research and independent study offerings, ARET 299 and 499 - Topics in ARET. These courses are better suited to projects that require more extensive work programs and additionally, are intended to operate over the entire academic semester. This led to the interest in developing and in-house internship program to address this need. The ARA Program has been designed to provide real project experiences to the student, while allowing professional firms and industrial companies to obtain a specific limited scope services at substantially reduced cost. The ARA Program provides a wide range of services specifically suited to short duration projects while maintaining direct supervision by the architects, professional engineers, and industrial managers of the client. The ARA Program was developed in the May of 2004 with an initial project and has seen constant expansion since that time. The program has obtained additional support from several new clients and thus far has performed to the required standards.

Implementation of the Applied Research Assistant program in Architectural Engineering Technology(ARET) at Bluefield State College (BSC) will strengthen our capacity to continually improve the quality of undergraduate education for students seeking careers and graduate study in architecture, engineering and construction (AEC) professions. Implementation of the ARA program will directly improve student opportunities and improve the quality of their learning environments. Also through the work program and scholarship options, the department anticipates increasing both the number and diversity of underrepresented students; women, region bound students and persons with disabilities seeking meaningful participation and leadership roles in the AEC professions. 


\section{Project Description}

Bluefield State College has emerged as a four-year state supported commuter college serving southeastern West Virginia with a primary thrust in the direction of professional and technical two- and four-year programs. The liberal arts offerings of the college are focused to enhance its unique mission. The college offers baccalaureate and associate degrees. Instructional programs are offered in engineering technologies, business, teacher education, arts and sciences, nursing and health science professions, and a variety of career fields. Students may also complete the non-traditional Regents Bachelor of Arts degree through Bluefield State College. One of the many strengths of the college has been the "two-plus-two" design of many of its baccalaureate level programs whereby the two years completed for an associate degree are applicable toward the baccalaureate degree. Bluefield State College is also dedicated to offering a wide variety of off campus and online courses.

The mission of Bluefield State College is to provide students an affordable, universally accessible opportunity for public higher education. The college demonstrates its commitment to undergraduate education by providing a dedicated faculty and staff, quality educational programs, and strong student support services in a caring environment. All programs are designed to promote the student's intellectual, personal, ethical, and cultural development. As a historically black institution, Bluefield State College prepares students for challenging careers, graduate study, informed citizenship, community involvement, and public service in an everchanging global society. The college serves the citizens of southeast West Virginia by providing programs principally at sites in Mercer, Greenbrier, Monroe, McDowell, Raleigh, Pocahontas and Summers counties and in some locations contiguous to its service area.

The Center for Applied Research \& Technology, Inc., was established on 28 July 1998 to enhance the competitive position of Bluefield State College for applied research opportunities in the current environment for research and development. Its goals are to promote the general economic development of the region; expedite and simplify the acquisition and utilization of research contracts; improve technology transfer; and link applied scientific research and technological advancements to economic development of the State of West Virginia. CART is a non-profit, non-stock corporation under the general corporation laws of the state organized exclusively for educational and scientific purposes within the meaning of section 501(c) [26 U.S.C. § 501(c) of the Internal Revenue Code of 1986, as amended, to foster and support applied research at the Bluefield State College School for Engineering Technology \& Computer Science and to provide evaluation, development, patenting, management and marketing for the inventions and diverse service capabilities of its students, faculty, and staff. CART operations are subject to an independent audit.

The Architectural Engineering Technology (ARET) baccalaureate program has been TAC of ABET accredited since 1992. Students are provided the opportunity to analyze the role of architecture in the building construction industry. Course work has involved developing skills in graphic communication, CAD proficiency, building design, and the basic engineering and analysis of building structures. Graduates are provided with a wide range of employment and graduate school opportunities in architectural design, construction estimating, general contracting, government planning agencies, and building material science. 
The primary goal of ARA Program is to provide junior and senior level students with some practical experience working on real projects through an in-house scholarship experience. The program offers professional firms and industries the opportunity for ARET students to perform some of the more mundane in activities involved in their practice at substantially reduced costs, freeing their staff to work on more complex elements. The program projects thus far have provided a wide variety of limited scope services, including existing conditions drawings, photographic documentation, site analysis data collection, and several types of drafting services. Students have had to adapt to differing drawings formats and styles that are unique to individual clients. The services provided under the ARA program remained under the direct supervision of the client.

\section{Project Overviews:}

\section{Data Collection:}

Projects in this category have involved:

- field measurements of existing buildings

- planemetric drawings,

- digital photography,

- site inventory and analysis, and

- product research

\section{Architectural Drafting:}

Projects in this category have involved:

- floor plan layouts developed from preliminary sketches, dimensioning,

- referencing and schedules,

- $\quad$ "Red Line" corrections, and

- 3D modeling

\section{Architectural Design:}

Projects in this category have involved:

- residential designed for custom homes, and

- renovation work - kitchens, bathrooms

\section{Drafting and Graphic Services:}

Projects in this category have involved:

- CAD drawing services to companies for standard and custom parts, and

- drawing formatting

\section{"As - Built" Drawings:}

Projects in this category have involved:

- documentation of variations between original construction documents and actual construction of the final project,

- field measurements of existing buildings 
- planemetric drawings, and

- digital photography

CART-Course Management System (CMS) Development:

Projects in this category include the following:

- students involved with our CMS performed research and course development activities for online versions of courses by;

- moving course content from classroom lecturer formats to online delivery versions,

- generating online course materials; homework answers, quiz and examination questions, and

- uploading and downloading course materials to the CART CMS site

\section{Scholarly Presentations:}

ARA students will be attending and making presentations to state and local conferences,

- conducting presentations on ARA Program projects and research to local civic organizations,

- preparing poster sessions at "Undergraduate Research Day" WV State Capitol,

- posting web enabled walk-through mpeg files of building designs on www.cartlink.org, and

- developing some "That's ARAP" marketing materials

\section{Funding}

The CART ARA Program has partnered with a BSC administration; Academic Vice President for Student Affairs, Director of Finance and Administration, and the Payroll Officer to establish a category funding mechanism to operate the program. An initial project was undertaken to provide working funds to begin the project. Fees from this project have been placed in a fund to provide resources to pay the students for their experience. Work is performed for the clients; fees are collected and placed in the fund. Student payroll and scholarships are drawn from this fund when needed.

ARA Program Students are offered two options; hourly pay for work completed or a semester by semester scholarship program. In the hourly pay option, students are considered employees of the college, keeping bimonthly time cards, and are been issued payroll by the State of West Virginia. Payroll tabulation, timekeeping and recording are performed by BSC Accounting Office. Under the scholarship option, students elect to receive payment as a scholarship issued by CART. Scholarships are issued to cover the cost of tuition, fees, and a book allowance. The scholarship students are required to submit time records, periodic reports of evidence of progress, and conduct presentations at the end of the semester to a review board made up of the CART Board of Directors.

Program operations will be handled by the CART ARA Program project manager. The project manager is responsible for scheduling, client contacts, record-keeping, and client billing. The fee amounts charged to each client are devised by a proposal and negotiation process, that to date have involved hourly rate charges and total fee amounts. Administrative charges are assessed by CART and included in client fees. 


\section{Project Descriptions}

Since the inception of the project in May of 2003, the program has become involved in a wide variety of projects. The following is a list of projects underway to date:

Twin Branch Recreation Area, Davy, West Virginia - design and construction documents for the site layout, vacation cabins, and bathhouse building,

US Properties, Bluefield, Virginia - interior renovations of a tenant space to be leased for commercial uses,

Craddock Residence - design and construction documents for a 2500 S.F. private residence,

Brewster Residence - private residence - kitchen and bathroom renovation

Industrial Plating, Princeton, West Virginia - CAD drafting of industrial parts, preparation of CAD drawings for discontinued and custom hydraulic components,

\section{Conclusions:}

CART will implement research based teaching and learning techniques and practices by championing the open-ended discovery of ideas through project-based teaching and natural association of applied research with architectural education. Our experience has shown that students respond well to application-based research and demonstrate more self-motivation and self-discipline when challenged to solve real problems. The project manager works closely with our industrial partners to identify project opportunities that fit well with the objectives of all concerned. CART seeks to regularly support fifteen ARA Program students within three years and thirty students within five years.

CART will integrate student research and other active learning opportunities into ARET curricula by including as an integral part of the ARET program the expansion of the Applied Research Assistant Program to include more department students. The ARA rogram is a scholarship based initiative, providing ARET students with the opportunity to apply practical work experience in the completion of some course credits, build a stronger resume, and offset some of the costs of attending, while working with local architectural offices and industrial corporations. Adequate funding would also facilitate student assistance in research capacities: providing CART-CMS operational activities support, staffing help desks, researching new online practices, and providing tutorials for new students.

CART will support internships or cooperative education opportunities through ARA Program which is essentially a low-residency internship where students will be financially supportive through cooperative agreements beneficial to both our students and the industrial partners, which include architects, engineers, manufacturers, and other service industries. The project manager will work closely with our industrial partners to identify project opportunities that fit well with the objectives of all concerned. 
DONALD BURY is a of Professor of Architectural Engineering Technology at Bluefield State College, Bluefield, West Virginia in the School of Engineering Technology and Computer Science. He is a registered Architect in the State of West Virginia. He received a Bachelor of Science in Architectural Studies from Washington State University in 1972, and a Master of Architecture in Urban Design from Virginia Tech in 1976.

BRUCE V. MUTTER, the director of the Center for Applied Research \& Technology, Inc. (CART), and is an Associate Professor at Bluefield State College in the School of Engineering Technology. He earned his B.S. degree in Architectural and Civil Engineering Technology from Bluefield State College, and his M.S. degree in Architecture and C.A.G. in Environmental Design and Planning from Virginia Tech. He is a current Ph.D. candidate at Virginia Tech. 